\title{
Inhibisi Korosi Pada Baja Lunak Dalam Media Air Gambut Dengan Metode Elektroplating
}

\author{
Munawaroh Nasailul Choli1 ${ }^{1)}$, Dwiki Ramadhan ${ }^{2)}$, dan Yulita Maulidia ${ }^{3)}$ \\ ${ }^{1,2)}$ Prodi Teknik Kimia, Jurusan Teknik Elektro, Jurusan Teknik Elektro, \\ 3) Prodi Teknik Lingkungan, Jurusan Teknik Sipil, Fakultas Teknik, Universitas TanjungpuraPontianak \\ email: ${ }^{1)}$ munawwaroh.nashailul@yahoo.com, ${ }^{2}$ dwikiramadhan46@gmail.com, ${ }^{3)}$ maulidiayulita@yahoo.com
}

\begin{abstract}
Abstrak-Korosi merupakan permasalahan yang umum terjadi pada penggunaan material-material berbasis logam. Laju korosi semakin dipercepat ketika material logam mengalami kontak langsung dengan senyawa-senyawa korosif seperti air gambut. Tanah gambut mempunyai sifat-sifat fisik yang kurang baik bagi keperluan konstruksi dan material logam karena dapat mengakibatkan kerusakan pada material logam, seperti korosi dan ketahanan material logam yang semakin berkurang. Kalimantan Barat merupakan daerah yang memiliki lahan gambut paling luas diIndonesia. Kalimantan Barat sendiri memiliki pH air gambut yaitu 3-5, dimana air gambut sangat asam dan sangat korosif. Seiring dengan berjalannya waktu material konstruksi tersebut akan mengalami korosi. Korosi dapat menyebabkan peningkatan biaya maintenance yang dikeluarkan dan pemborosan sumber daya mineral. Berbagai upaya telah dilakukan untuk memproteksi logam dari korosi diantaranya dengan metode elektroplating yang merupakan mekanisme perlindungan katoda, serta penggunaan inhibitor sebagai pelapis korosi. Penelitian ini bertujuan untuk mengetahui efektifitas inhibitor korosi dari kitosan limbah cangkang rajungan (Portunus pelagicus) pada baja lunak dalam medi air gambut dengan metode elektroplating. Spesimen yang digunakan adalah baja lunak. Proses elektroplating dilakukan dalam larutan elektrolit yang mengandung inhibitor kitosan limbah cangkang rajungan (Portunus pelagicus) konsentrasi $10 \%$ dengan lama elektroplating 3 jam pada tegangan 20 volt. Perendaman logam dalam air gambut pH 5 selama 1, 3 dan 5 hari. Pengujian kitosan dilakukan dengan analisis FTIR, sedangkan pengujian laju korosi dilaksanakan dengan metode perhitungan. Hasil penelitian menunjukkan bahwa kitosan yang diperoleh memiliki derajat deasetilasi $85,31 \%$. Hasil perendaman air gambut berturut-turut pada 1, 3 dan 5 hari dengan $\mathrm{pH}$ air gambut 5 , yaitu $0,0045 \mathrm{gr} / \mathrm{cm}^{2}$.jam, 0,0056 $\mathrm{gr} / \mathrm{cm}^{2}$.jam, 0,0089 $\mathrm{gr} / \mathrm{cm}^{2} . j \mathrm{jm}$. untuk hasil dari nilai efisiensiinhibisi sebesar $63,52 \%$.
\end{abstract}

Kata Kunci:Elektroplating, inhibitor, korosi, kitosan

\section{Pendahuluan}

Indonesia merupakan salah satu negara yang memiliki luas lahan gambut terbesar di dunia yaitu 10,8\% dari luasan daratan Indonesia [1]. Lahan gambut diIndonesia mencapai 14,9 juta ha atau 7,8\% dari total wilayah Indonesia 191,09 juta ha. Lahan gambut diIndonesia terutama terdapat di Sumatra, Kalimantan dan Papua. Kalimantan sendiri memiliki luas tanah gambut mencapai 4,7 juta ha atau $32,1 \%$ dari luas gambut diIndonesia. Kalimantan Barat menjadi peringkat pertma dengan luas 1.680 .134 ha atau $73,8 \%$ dari luas gambut di Kalimantan Barat [2].

Manuscript received 05-07-2018; revised 16-08-2018; accepted 23-09-2018
Bangunan dan konstruksi Kalimantan Barat rata-rata melewati tanah gambut, sedangkan tanah gambut mempunyai sifat-sifat fisik yang kurang baik bagi keperluan konstruksi, baik itu untuk pondasi bangunan, pipa-pipa saluran bawah tanah, maupun untuk tangkatangki penyimpanan. Seiring dengan berjalannya waktu material konstruksi tersebut akan mengalam korosi. Korosi dapat menyebabkan peningkatan biaya maintenanceyang dikeluarkan dan pemborosan sumber daya mineral. Hingga saat ini, para ilmuan telah melakukan berbagai penelitian mengenai metode perlindungan korosi, namun metode yang sudah ada harganya masih relatif mahal, sehingga membutuhkan solusi untuk mengatasi masalah tersebut.

Beberapa cara yang dapat memperlambat laju reaksi korosi diantaranya, penambahan zat tertentu yang berfungsi sebagaiinhibitor reaksi korosi [3]. Pada penelitian yang telah dilakukan terdahulu, terdapat berbagai macam inhibitor yang digunakan, salah satunya adalah inhibitor kitosan. Menurut penelitian [4]kitosan dapat digunakan sebagaiinhibitor korosi pada baja dalam air gambut. Adapun kondisi optimum kitosan terjadi pada $\mathrm{pH} 3$, teknik inhibisinya pelapisan dan waktu interaksi selama 3 hari yaitu sebesar 88,73\%, sedangkan kitosan (2) terjadi pH6, teknik inhibisinya pencelupan dan waktu interaksi selama 3 hari yaitu sebesar $93,32 \%$. Namun dalam penelitian tersebut metode yang digunakan kurang maskimal sehingga dapat menyebabkan pelapisan korosi tidak bertahan lama serta kemungkinan pelapisan tidak bertahan lama.

Oleh karena itu dalam penelitian ini perlu dilakukan untuk menambah pengetahuan tentang pemanfaatan kitosan dari limbah cangkang rajungan (Portunus pelagicus) sebagaiinhibitor korosi pada baja lunak dalama media air gambut serta menggunakan perkembangan metode yang berbeda yaitu metode elektroplating untuk mengetahui hasil maksimal dari teknik pelapisan korosi.

\section{Metodologi Peneltian}

Langkah-langkah penelitian ini dapat dijelaskan sebagai berikut :

a. Waktu dan Tempat Pelaksanaan Penelitian

Penelitian ini dilaksanakan selama kurang lebih 3 bulan, mulai dari bulan April 2018 sampai bulan Juni 2018. Proses elektroplating dilaksanakan di Laboratorium Teknik Kimia Universitas Tanjungpura, Laboratorium Mekanika Tanah Teknik Sipil, Universitas Tanjungpura Pontianak. Air gambut yang digunakan dalam penelitian ini berasal dari daerah Serdam Kubu Raya, Kalimantan Barat. 
Karakterisasi menggunakan instrumen FTIR dilakukan di Laboratorium Kimia FMIPA, UGM, Yogyakarta.

\section{b. Alat dan Bahan}

Alat yang diperlukan dalam penelitian ini adalah Power Supply (BK-Precision DC), elektroda Pt, film titanium, dan pengaduk magnetik. Sistem reaktor fotoelektrokimia terdiri atas lampu UV. Peralatan analisis terdiri atas FTIR. Selain itu seperangkat alat gelas dan penunjang laboratorium lainnya yang terdiri atas neraca analitik, oven, tanur, dan desikator.

Sedangkan bahan yang digunakanadalah plat titanium, kawat platina, limbah cangkang rajungan (Portunus pelagicus), $\mathrm{NaOH}$ (Merck), $\mathrm{HCl}$ (Merck), gliserol 98\% p.a (Merck), akuades,air gambut, etanol p.a (Merck), kertas abrasif, aseton p.a (Merck), natrium format (HCOONa) (Merck) 0,05 M.

\section{c. Prosedur Penelitian}

1. Preparasi sampel

Sampel limbah cangkang rajungan (Portunus pelagicus) dilakukan proses demineralisasi menggunakan larutan $\mathrm{HCl}$ dengan perbandingan cangkang kering dan $\mathrm{HCl}$ 1:1,5 (b/v) lalu dicuci kembali sampai netral. Tahap selanjutnya diproteinasi dengan menggunakan $\mathrm{NaOH}$, kemudian tahap deasetilasi dengan memanaskan cangkang dalam larutan $\mathrm{NaOH} 50 \%$ pada suhu $110^{\circ} \mathrm{C}$ selama 5 jam. Kitosan yang diperoleh dianalisis dan divalidasi menggunakan spektrofotometer IR.

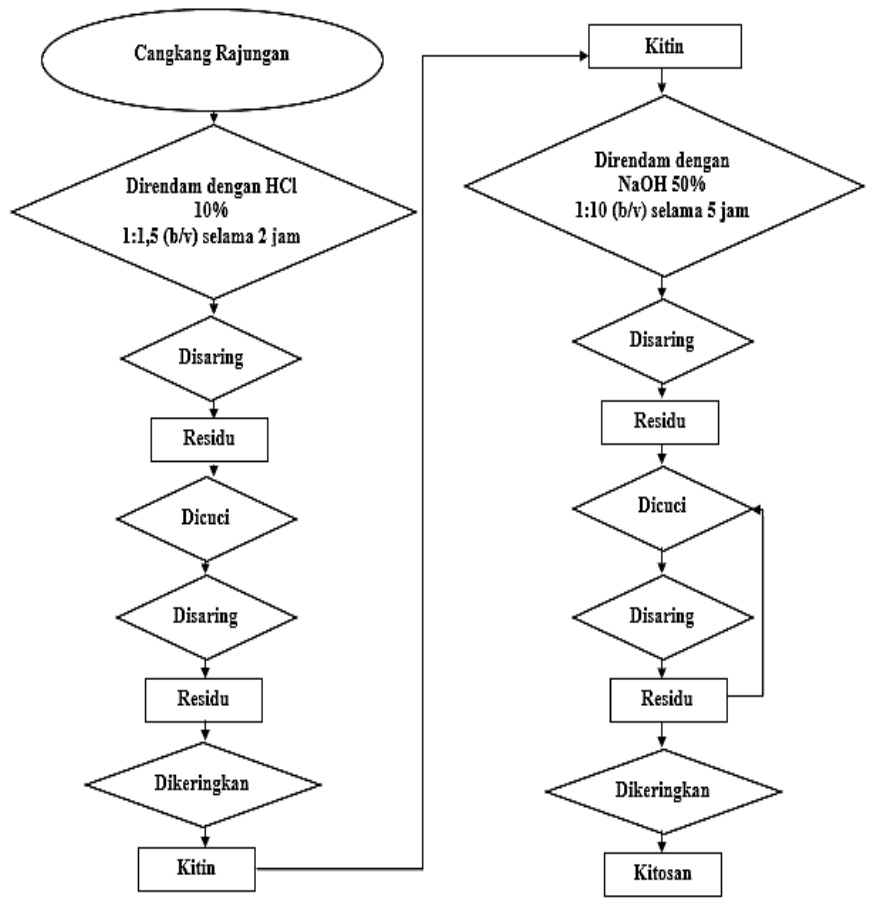

Gambar 1. Pembuatan kitosan limbah cangkang rajungan (Portunus pelagicus)

2. Pengujian dengan Media Air Gambut

Baja lunak direndam pada media air gambut. Pengukuran berat hilang spesimen lempengan baja lunak ditimbang dan kemudian direndam dalam $10 \mathrm{~mL}$ air gambut tanpa dan dengan kitosan dengan $\mathrm{pH}$ air gambut 5, waktu perendaman 1,3 , dan 5 hari. Kemudian spesimen dibilas dan dicuci dengan akuades serta dikeringkan dalam oven pada suhu $60^{\circ} \mathrm{C}$ dan ditimbang kembali.

\section{Metode Elektroplating}

Elektroplating adalah sautu proses pelapisan logam dengan logam lain dengan caara elektrolisa. Tujuannya adalah untuk melindungi logam yang mudah rusak karena udara (korosi) dengan logam yang lebih tahan. Prinsip kerja elektroplating adalah dengan menggunakan katoda berupa logam yang akan dilapisi, anoda berupa logam untuk melapisi, dan larutan elektrolit berupa garam dari anodanya [5].

Elektroplating merupakan cara pelapisan permukaan substrat yang berlangsung dalam larutan elektrolit. Substrat berfungsi sebagaikatoda sedangkan anoda merupakan sumber yang nantinya berfungsi sebagai bahan pelapis terhadap substrat. Arus listrik searah (DC) dialirkan ke anoda dan katoda. Adanya pelapisan diharapkan akan dapat menahan laju mobilitas dislokasi di permukaan bahan, sehingga akan memperkuat sifat kekerasan, dan ketahanan korosi. Kelebihan dari teknik elektroplating anatara lain karena elektroplating dapat dilakukan pada suhu kamar sehingga tidak menimbulkan distorsi atau perubahan struktur pada substrat [6].

Uji anti korosi dilakukan pada sistem reaktor fotoelektrokimia yang terdiri atas 2 kompartemen yaitu sel anoda dan sel korosi (sel katoda) yang dilengkapi dengan sumber cahaya UV. Pada mulanya permukaan dan sisi logam diampelas hingga mengkilap. Lalu diukur dimensi dan massa awal logam. Kemudian logam diikat dan dicuci dengan aseton. Setelah itu dikeringkan dan logam siap dielektroplating.

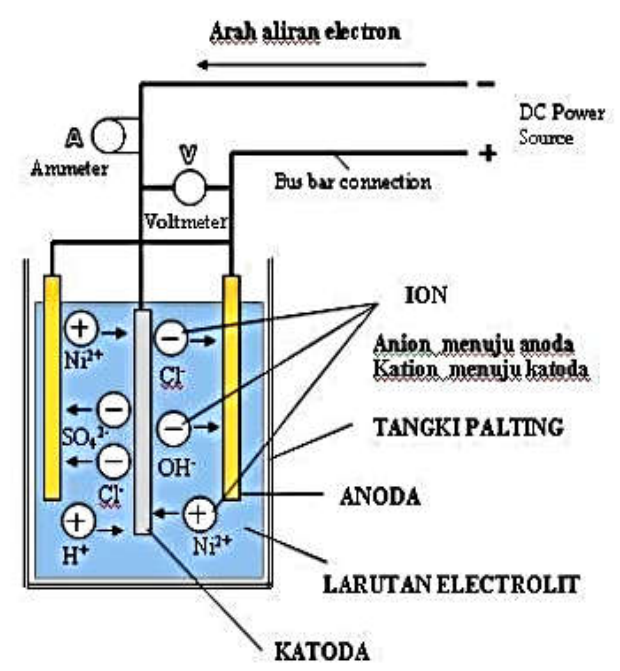

Gambar 2. Skema proses elektroplating [7]

Hasil dari penelitian perubahan dari spesimen dapat dilihat dengan pengukuran laju korosi, sehingga diketahui efisiensiinhibisinya. Pengukuran laju korosi dapat menggunakan rumus berikut:

$$
\text { Laju Korosi }=\frac{K \cdot W}{D \cdot A \cdot t}
$$

Dimana:

$\mathrm{K}=$ Konstanta (mmpy 8,76×10 $10^{6}$ )

$\mathrm{W}=$ Kehilangan berat (gram) 
$\mathrm{D}=$ Densitas logam $\left(\mathrm{gr} / \mathrm{cm}^{3}\right)$

$\mathrm{A}=$ Luas permukaan $\left(\mathrm{cm}^{2}\right)$

$\mathrm{t}=$ Waktu

$$
E f \text { isiensiinhibisi }=\frac{V k o-V k \mathrm{i}}{\mathrm{Vki}} x 100 \%
$$

Dimana, Vko = laju reaksi tanpa inhibitor $\mathrm{Vki}=$ laju reaksi dengan inhibitor

\section{Hasil dan Pembahasan}

\subsection{Pembuatan Kitosan dan Karakterisasinya}

Pada penelitian ini digunakan limbah cangkang rajungan (Portunus pelagicus) sebagaiinhibitor untuk baja lunak dalam media air gambut. Prosedur sintesis kitosan limbah cangkang rajungan (Portunus pelagicus) didasarkan pada penelitian yang telah dilakukan [8]. Untuk mengenentukan derajat deasetilasi digunakan metode garis oleh Moore dan Robert, seperti ditunjukkan dalam persamaan berikut:

$$
\left[1-\left(\frac{A_{1588}}{A_{3410}} X \frac{1}{1.33}\right)\right] X 100 \%
$$

dengan :

$$
\begin{array}{ll}
\mathrm{A} & =\log (\mathrm{Po} / \mathrm{P})=\text { absorbansi } \\
\mathrm{A}_{1588} & =\text { absorbansi pada panajang gelombang } \\
& 1588 \mathrm{~cm}^{-1} \text { untuk serapan gugus } \\
& \text { amida/asetamida }\left(\mathrm{CH}_{3} \mathrm{CONH}\right) \\
\mathrm{A}_{3410} & =\text { absorbansi pada panjang gelombang } 3410 \mathrm{~cm}^{-1} \\
& \text { untuk serapan gugus hidroksil }\left(\mathrm{OH}^{-}\right) .
\end{array}
$$

Berdasarkan persamaan di atas, maka kitosan dari limbah cangkang rajungan (Portunus pelagicus) yang diperoleh dari penelitian ini memiliki nilai derajat deasetilasi sebesar 85,31\%.Gambar di bawah ini menunjukkan hasil karakterisasi kitosan limbah cangkang rajungan (Portunus pelagicus) menggunakan FTIR.

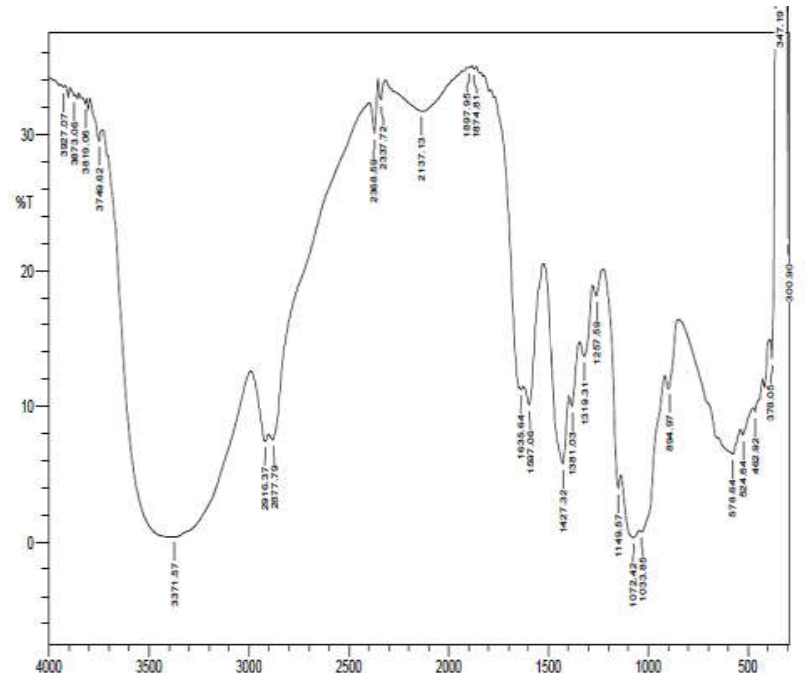

Gambar 3. Spektrum FTIR kitosan limbah cangkangrajungan (Portunus pelagicus)

\subsection{Pengujian Media Air Gambut}

Air gambut yang digunakan sebagai media memiliki $\mathrm{pH}$ 5 sesuai kondisipHair gambut Kalimantan Barat dengan waktu perendaman $1,3,5$ hari (a)

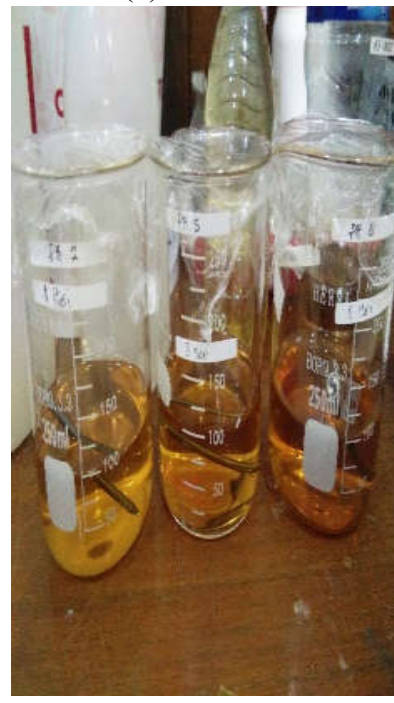

(b)

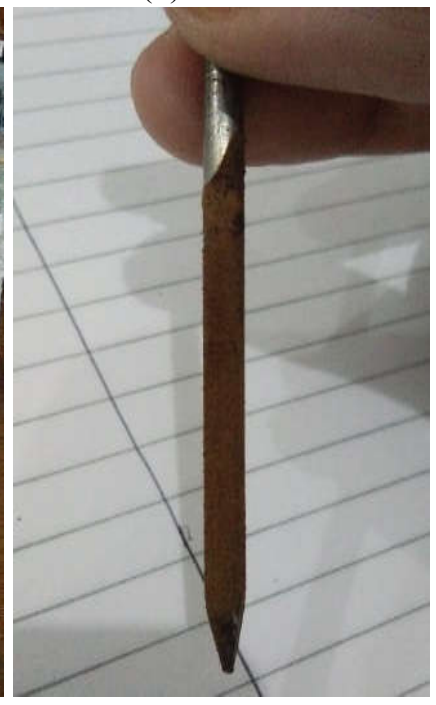

Gambar 4. Baja lunak sebelum dan sesudah mengalami korosi (a) sebelum (b) sesudah perendaman air gambut.

Dalam proses terjadinya korosi pada baja lunak yang diteliti, baja yang direndam tersebut akan mengalami penetrasi atau difusi dari larutan induk media korosif gambut. Hal ini dapat mempengaruhi nilai dari resistensi yang dimiliki oleh baja lunak tersebut ketika dialiri arus dan kadar $\mathrm{O}_{2}$ yang ada pada larutan memiliki peranan dalam proses oksidasi terhadap baja lunak sehingga terjadi korosi. Dapat dilihat dariGambar 3 bahwa pada spesimen baja lunak telah mengalami perubahan yang diakibatkan oleh korosi.

\subsection{Elektroplating}

Metode elektroplating dilakukan dengan menyiapkan 2 elektroda, plat titanium pada sel anoda dan kawat Pt pada sel katoda yang terhubung dengan Power Supply. Kedua elektroda dicelupkan dalam larutan gliserol yang mengandung konsentrasi kitosan 10\% serta air 25\%. Proses anodisasi menghasilkan gelembung gas hidrogen di sekeliling kawat Pt pada tegangan 20V DC dan disertai pengadukan menggunakan magnetik stirer selama 3 jam. Berikut gambar hasil perlakuan elektroplating.

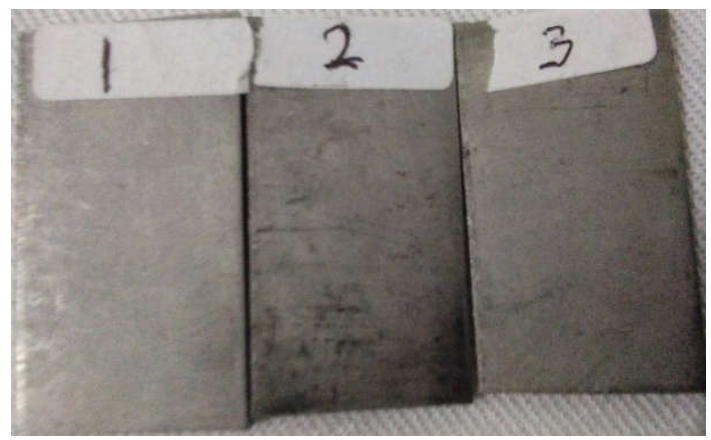

Gambar 5. Plat titanium sebelum elektroplating 


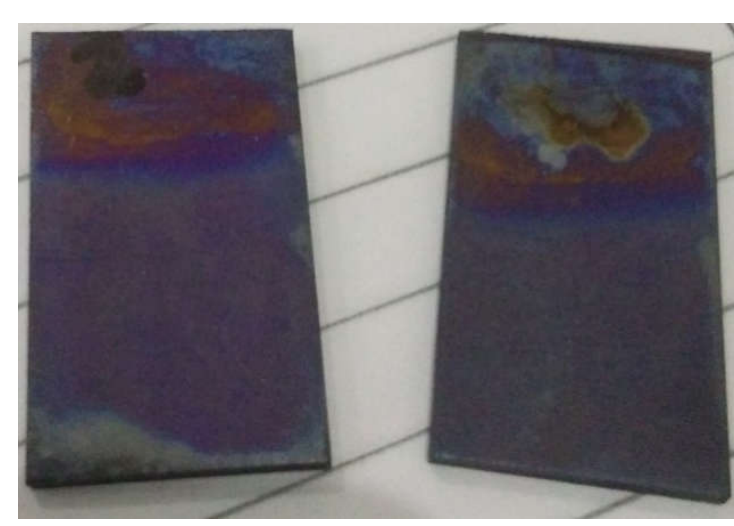

Gambar 6. Plat titanium sesudah perlakuan elektroplating

Keberhasilan proses anodisasi diindikasikan dengan munculnya gelembung gas hidrogen pada kawat Pt serta evolusi arus yang sesuai tercatat selama proses anodisasi. Tahap awal, pembentukan lapisan tipis oksida $\mathrm{TiO}_{2}$ terjadi pada sampel logam titanium dalam larutan elektrolit. Adanya medan listrik menginduksi reaksi oksidasi pada anoda titanium dan reduksi pada katoda kawat Pt. Reaksi yang terjadi pada anoda dan katoda diberikan pada persamaan (4) dan (5):

Reaksi katoda: $2 \mathrm{H}_{2} \mathrm{O}\left({ }_{1}\right)+2 \mathrm{e}^{-} \rightarrow \mathrm{H}_{2(\mathrm{~g})}+2 \mathrm{OH}_{(\mathrm{aq})}^{-}$

Reaksi anoda: $\mathrm{Ti}_{(\mathrm{s})}+2 \mathrm{H}_{2} \mathrm{O}_{(\mathrm{l})} \rightarrow \mathrm{TiO}_{2(\mathrm{~s})}+4 \mathrm{H}_{(\mathrm{g})}^{+}+4 \mathrm{e}^{-}(5)$

Reaksi oksidasi titanium terjadi pada anoda membentuk lapisan tipis oksida $\mathrm{TiO}_{2}$. Sedangkan pada katoda terjadi reduksi air melepas gas $\mathrm{H}_{2}$ dibuktikan dengan munculnya gelembung gas di sekitar kawat $\mathrm{Pt}$ selama proses sintesis $\mathrm{TiO}_{2}$ yang terbentuk diharapkan teradsorpsi ke dalam pori kitosan sehingga membentuk nanokomposit kitosan $\mathrm{TiO}_{2}$.

\subsection{Penentuan dan Uji Laju Korosi}

Proses korosi berlangsung secara spontan dan tidak dapat dicegah, tetapi hanya dapat dihambat agar proses korosi terjadi sekecil mungkin. Pada penelitian ini dilakukan penghambatan proses korosi baja lunak dalam media air gambut dengan menggunakan inhibitor kitosan limbah cangkang rajungan (Portunus pelagicus). Sedangkan lingkungan korosif menggunakan air gambut $\mathrm{pH}$ 5. Pengujian laju korosiini didasarkan pada reduksi berat yang terjadi pada material ketika dicelupkan dalam media. Penambahan larutan inhibitor kitosan limbah cangkang rajungan (Portunus pelagicus) dalam larutan air gambut sebagai media korosinya, dilakukan dengan konsentrasi $10 \%$. Setelah benda uji direndam, pengambilan dilakukan sebanyak 3 kali yaitu pada hari ke-1, 3, dan 5 .

Substrat yang telah dilapisiinhibitor kitosan limbah cangkang rajungan (Portunus pelagicus) diuji ketahanan korosinya. Pengujian dilakukan dengan metode menggunakan persamaan (1) sesuai[9]. Sampel ditimbang massa awal dan diukur dimensinya (panjang, lebar, dan ditimbang massa akhirnya untuk menghitung massa yang hilang selama proses korosi. Besarnya massa yang hilang (W) dapat dihitung dengan persamaan (3).
$\mathrm{W}=$ massa awal $\left(\mathrm{W}_{1}\right)$ - massa akhir $\left(\mathrm{W}_{2}\right)$

Berikut tabel hasil pengukuran baja lunak dengan perendaman air gambut $\mathrm{pH} 5$ yang diperoleh :

\subsection{Pengaruh Perendaman Terhadap Laju Korosi}

Adanya kitosan limbah cangkang rajungan (Portunus pelagicus) yang ditambahkan pada sel elektrokimia membuat molekul-molekul kitosan teradsorpsi pada logam, akibatnya lapisan pelindung yang terbentuk pada permukaan baja lunak semakin banyak sehingga tahanan yang terbentuk semakin besar dan mengakibatkan rapat arus korosi yang terdeteksi oleh elektroda bantu semakin berkurang. Berikut tabel data laju korosi yang diperoleh :

Tabel 1. Data Laju korosi baja lunak direndam dalam air gambut tanpa penambahan inhibitor kitosan limbah cangkang rajungan (Portunus pelagicus) (inhibitor 0\%)

\begin{tabular}{ccccc}
\hline $\begin{array}{c}\text { Waktu } \\
\text { perendaman } \\
\text { (hari) }\end{array}$ & $\begin{array}{c}\text { Berat } \\
\text { awal } \\
\text { (gram) }\end{array}$ & $\begin{array}{c}\text { Berat } \\
\text { akhir } \\
\text { (gram) }\end{array}$ & $\begin{array}{c}\text { Kehilangan } \\
\text { berat } \\
\text { (gram) }\end{array}$ & $\begin{array}{c}\text { Laju } \\
\text { korosi }\end{array}$ \\
\hline \hline Ke-1 & 3,96 & 3,93 & 0,01 & 0,0045 \\
\hline Ke-3 & 3,93 & 3,91 & 0,02 & 0,0056 \\
\hline Ke-5 & 3,93 & 3,92 & 0,03 & 0,0089 \\
\hline
\end{tabular}

Tabel 2. Data Laju korosi baja lunak direndam dalam air gambut dengan penambahan inhibitor kitosan limbah cangkang rajungan (Portunus pelagicus) (inhibitor 10\%)

\begin{tabular}{ccccc}
\hline $\begin{array}{c}\text { Waktu } \\
\text { perendaman } \\
\text { (hari) }\end{array}$ & $\begin{array}{c}\text { Berat } \\
\text { awal } \\
\text { (gram) }\end{array}$ & $\begin{array}{c}\text { Berat } \\
\text { akhir } \\
\text { (gram) }\end{array}$ & $\begin{array}{c}\text { Kehilangan } \\
\text { berat } \\
\text { (gram) }\end{array}$ & $\begin{array}{c}\text { Laju } \\
\text { korosi }\end{array}$ \\
\hline \hline Ke-1 & 3,93 & 3,94 & 0,01 & 0,004 \\
\hline Ke-3 & 3,91 & 3,92 & 0,01 & 0,0045 \\
\hline Ke-5 & 3,93 & 3,94 & 0,01 & 0,004 \\
\hline
\end{tabular}

Pada tabel di atas menunjukkan perendaman air gambut tanpa perlakuan mengakibatkan peningkatan kehilangan berat sehingga laju korosi juga semakin meningkat. Hal ini dikarenakan proses reduksi yang terjadi pada baja lunak semakin besar dengan bertambahnya proses perendaman. Begitupun sebaliknya perendaman air gambut dengan penambahan inhibitor korosi mengalami penurunan laju reaksi, yang disebabkan adanya inhibitor kitosan limbah cangkangrajungan (Portunus pelagicus) yang membentuk lapisan tipis pada permukaan baja lunak. Hal ini terjadi karena adanya adsorpsi jumlah dan wilayah dariinhibitor pada baja lunak meningkat dengan adanya penambahan inhibitor. 


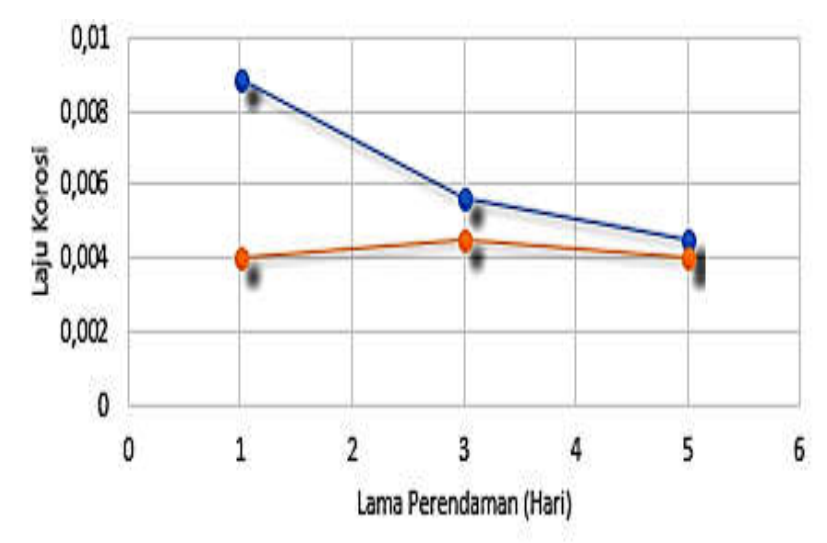

$\rightarrow-$ tanpa inhibitor $\rightarrow-$ denganinhibitor

Gambar 7. Grafik pengaruh perendaman air gambut terhadap laju korosi dengan inhibitor dan tanpa inhibitor

Spesimen dengan jumlah inhibitor yang ditambahkan sedikit akan teradsorpsi dalam jumlah sedikit pada permukaan spesimen dalam rentang waktu yang relatif masih singkat. Hal ini menyebabkan laju korosi yang cukup tinggi. Dengan semakin lamanya waktu perendaman adsorpsiinhibitor semakin banyak. Hal ini akan menyebabkan terjadinya penurunan laju korosi hingga pada suatu titik tertentu dimana adsorpsi sudah mencapai titik jenuh, hingga laju korosi menjadi cenderung konstan.

Suatu sistem yang terinhibisi ataupun tidak yang tidak terinhibisi akan cenderung menurun dengan adanya bertambahnya waktu. Penyebabnya hal ini bisa dari kontaminasi media digunakan.

\subsection{Mekanisme Inhibitor Kitosan Limbah Cangkang Rajungan (Portunus pelagicus)}

Senyawa kitosan ini memiliki beberapa gugus fungsi yang dapat berinteraksi dengan atom-atom baja lunak sehingga membentuk lapisan pelindung pada permukaan baja lunak. Gugus yang dimiliki kitosan adalah $\mathrm{NH}_{2}$ - dan gugus $\mathrm{OH}^{-}$yang dapat mebentuk kompleks dengan logam dari PEB yang dimilikinya. Inhibitor kitosan limbah cangkang rajungan (Portunus pelagicus) dalam air gambut mengalami protonasi pada gugus fungsi yang berperan penting dalam penghambatan korosi pada baja lunak. Molekul kitosan limbah cangkang rajungan (Portunus pelagicus) yang terprotonasiini kemudian berkompetisi dengan ion hidrogen $\left(\mathrm{H}^{+}\right)$untuk teradsorpsi pada situs katodik di permukaan logam sehingga pembentukan gas Hidrogen $\left(\mathrm{H}_{2}\right)$ menjadi berkurang. Ion klorida $\left(\mathrm{Cl}^{-}\right)$dalam media air gambut bereaksi dengan bagian logam yang bermuatan positif di permukaan baja lunak dan membuat ion negatif lainnya berkumpul pada bagian antar muka antara elektroda dan media korosif, sehingga molekul kitosan limbah cangkang rajungan (Portunus pelagicus) menjadi mudah untuk teradsorpsi pada situs anodik baja lunak. Mekanisme adsorpsi kitosan limbah cangkang rajungan (Portunus pelagicus) terprotonasi pada permukaan baja lunak ditunjukan pada Gambar 8 .

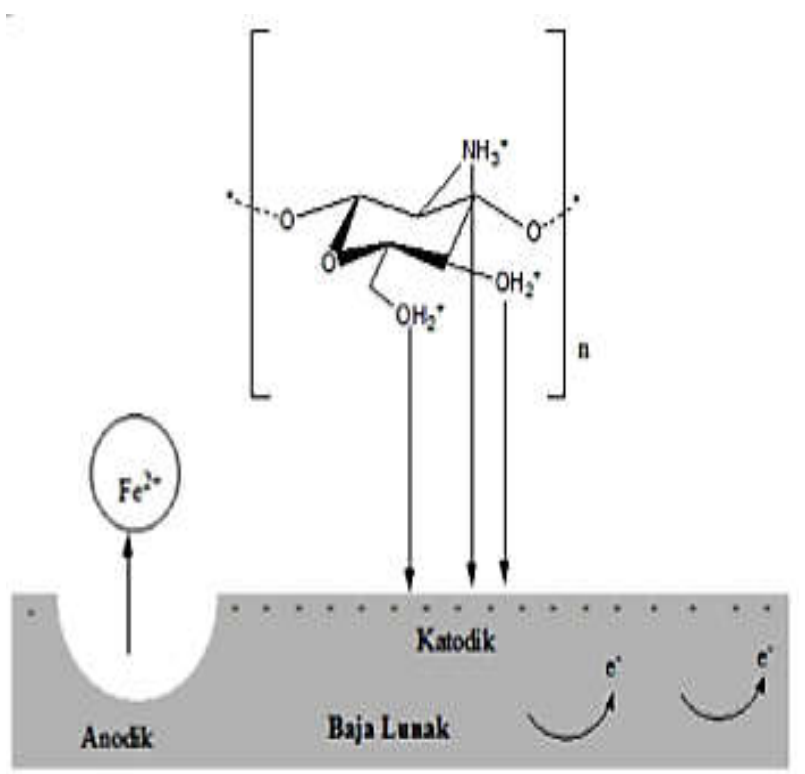

Gambar 8. Perkiraan interaksi elektrostatik antara kitosan limbah cangkang rajungan (Portunus pelagicus) dengan permukaan baja lunak[10]

Molekul netral diadsorpsi oleh baja lunak dengan mekanisme penggantian molekul air pada permukaan baja lunak.

\section{KeSIMPULAN}

Berdasarkan hasil penelitian yang telah dilakukan, maka kesimpulan yang dapat diambil yaitu:

1. Material kitosan limbah cangkang rajungan (Portunus pelagicus) merupakan bahan alternatif yang aman, mudah didapatkan, murah, dan ramah lingkungan serta efektif dalam pencegahan korosi menggunakan metode electroplating pada baja lunak. Khususnya untuksistem yang kontak langsung dengan liquid korosif.

2. Kitosan yang diperoleh dari limbah cangkang rajungan (Portunus pelagicus) memiliki derajat deasetilasi sebesar $85,31 \%$.

3. Laju reaksi korosi baja lunak tanpa penambahan inhibitor kitosan limbah cangkang rajungan (Portunus pelagicus) pada media korosif air gambut pada rendaman 1,3 , dan 5 hari mengalami kenaikan yaitu $0,0045 \mathrm{gr} / \mathrm{cm}^{-1}, \quad 0,0056 \mathrm{gr} / \mathrm{cm}^{-1}, 0,0089 \mathrm{gr} / \mathrm{cm}^{-1}$. Sedangkan laju reaksi baja lunak dengan penambahan inhibitor kitosan limbah cangkang rajungan (Portunus pelagicus) pada media korosif air gambut pada rendaman 1 , 3, dan 5 hari mengalami penurunan sebesar $0,004 \mathrm{gr} / \mathrm{cm}^{-1}, 0,0045 \mathrm{gr} / \mathrm{cm}^{-1}, 0,004 \mathrm{gr} / \mathrm{cm}^{-1}$.

4. Kitosan limbah cangkang rajungan (Portunus pelagicus) berpotensi sebagaiinhibitor korosi baja lunak dalam media air gambut pH 5 dengan konsentrasi 10\% dan nilai efisiensi sebesar $63,52 \%$. 


\section{UCAPAN TERIMA KASIH}

Terimakasih disampaikan penulis kepada Direktorat Jenderal Pembelajaran dan Kemahasiswaan Kementerian Riset, Teknologi, dan Pendidikan Tinggi yang telah mendanai penelitian ini dengan nomor : 1020/B3.1/KM/2018.

\section{Daftar Pustaka}

[1] Anggriawan, Ade, Edy S., Monita O, "Penyisihan Kadar Logam Fe dan Mn Pada Air Gambut dengan Pemanfaatan Geopolimer dari Kaolin Sebagai Adsorben," Jom. FTENIK, $2,1,2015$

[2] Ritung, Peta Lahan Gambut Indonesia, Balai Besar Litbang Sumber Daya Lahan Pertanian, Badan Penelitian dan Pengembangan Pertanian, Jakarta, 2011.

[3] Surdia, Efek Inhibitor Terhadap Sifat Korosi Paduan Logam $\mathrm{Cu}$ Oleh Air Laut, Korosi 1, PT. Pradya Pramita, Indonesia, 1979.

[4] Maria Erna, Emriadi, Admin Alif, Syukri Arief, "Efektifitas Kitosan sebagaiInhibitor Korosi pada Baja Lunak dalam Air Gambut”, Jurnal Natur Indonesia, 13(2), Februari 2011.

[5] Suwinardi, 1994, hubungan antara massa zat yang terbentuk dengan waktu dalam proses elektoplating. Laporan hasil penelitian Universitas Diponerogo Semarang: 16.

[6] Mulyaningsih, N., Iswanto, P.T., dan Soekrisno, "Pengaruh Waktu Elektroplating Nikel-Chrom Terhadap Kekerasan Baja Stainless Steel Arsi 304," Prosiding Seminar Nasional Aplikasi Sains \& Teknologi (SNAST) Periode III, 2012.

[7] Tretheway, K.R., Chamberlian, J., Korosi untuk Mahasiswa Sains dan Rekayasa, PT Gramedia Pustaka Utama, Jakarta, 1991.

[8] Ermawati dan Yunita, "Pemanfaatan Kitosan dari Limbah Rajungan (Portunus pelagicus) sebagai Antimikroba pada Obat Kumur,” UGM, Yogyakarta, 2009.

[9] ASTM D96, "Sediment Tests Water and Sediment in Crude oil, Guide to ASTM Test Methods", 2nd Edition-2007.

[10] Clarissa Welny Saleh, Harmami, dan Ita Ulfin "Pengendalian Korosi Menggunakan Inhibitor Kitosan Larut Air untuk Baja Lunak dalam Media $\mathrm{HCl} 1 \mathrm{M}$ “ Jurnal Sains Dan Seni ITS Vol.6, No.1, (2017) 2337-3520 